\title{
The right to education and study and women's labor rights in Iranian jurisprudence and law and the UNESCO 2030 document
}

\section{El derecho a la educación y el estudio y los derechos laborales de las mujeres en la jurisprudencia y el derecho iraníes y el documento de la UNESCO 2030}

\author{
OmolBanin Ali Bakhshzadeh \\ PhD Student, Department of Theology, Mashhad Branch, Islamic Azad University, Mashhad, \\ Iran \\ ORCID: https://orcid.org/0000-0002-9437-5932 \\ Moloud Garmroudi Sabet \\ Assistant Professor, Department of Theology, Mashhad Branch, Islamic Azad University, \\ Mashhad, Iran \\ ORCID: https://orcid.org/0000-0002-6697-4313 \\ Ozra Entekhabian \\ Assistant Professor, Department of Theology, Mashhad Branch, Islamic Azad University, \\ Mashhad Iran \\ ORCID: https://orcid.org/0000-0002-1952-3827
}

*Correspondence

Email: m.garmroudi@gmail.com
Cite as:

Bakhshzadeh, O., Garmroudi, M., \& Entekhabian, O. (2021). The right to education and study and women's labor rights in Iranian jurisprudence and law and the UNESCO 2030 document. Propósitos y Representaciones, 9 (SPE3), e1022. Doi: http://dx.doi.org.10.20511.pyr2021.v9nSPE3.1122 


\section{Summary}

In this article, the researcher seeks to examine the right to education and study and women's labor rights in Iranian jurisprudence and law and the 2030 UNESCO document. The present study is a descriptive-analytical study using the library method to investigate the question. The results of the study indicate that both in Islam and Iranian law, as well as in international documents, the equality of women's rights with men is emphasized but the concept of equality in Islam is explained in the sense of proportion and not equality in international instruments, however, equality between men and women means that their rights are equal. Regarding the right to education, there is no contradiction between Iranian jurisprudence and law and the 2030 document because in both Iranian jurisprudence and law, as well as in the documents emphasized in the 2030 document, which leads to the empowerment of women, the right to equal education has been emphasized. Regarding labor rights, it should be said that in the conventions of the International Labor Organization, which are among the documents considered in the 2030 document in the field of women's empowerment, concessions in the field of women's labor rights have been included for them. Prohibition of hazardous work, breastfeeding hours, maternity leave are among these rights. In Iranian labor law, these advantages are also considered for women, and therefore it seems that Iranian labor law is in accordance with international instruments. The issue of equality can be analyzed in such a way that, although there are biological and natural differences between men and women, this situation should not lead to legal differences. Basically, biological differences are concerned with the realities of human existence, and the legal debate is concerned with human needs and although individuals are different in existential realities, they can also be similar in legal requirements.

Keywords: Right to Education, Women's Labor Law, Iranian Jurisprudence and Law, UNESCO 2030 Document

\section{Resumen}

En este artículo, la investigadora busca examinar el derecho a la educación y el estudio y los derechos laborales de las mujeres en la jurisprudencia y el derecho iraníes y el documento de la UNESCO de 2030. El presente estudio es un estudio descriptivo-analítico que utiliza el método de biblioteca para investigar la pregunta. Los resultados del estudio indican que tanto en el Islam como en la ley iraní, así como en documentos internacionales, se enfatiza la igualdad de los derechos de las mujeres con los hombres, pero el concepto de igualdad en el Islam se explica en el sentido de proporción y no de igualdad en los instrumentos internacionales. Sin embargo, la igualdad entre hombres y mujeres significa que sus derechos son iguales. En cuanto al derecho a la educación, no hay contradicción entre la jurisprudencia y ley iraní y el documento de 2030 porque tanto en la jurisprudencia y la ley iraníes, como en los documentos enfatizados en el documento de 2030, que conduce al empoderamiento de la mujer, el derecho a la Se ha hecho hincapié en la igualdad de educación. En cuanto a los derechos laborales, cabe decir que en los convenios de la Organización Internacional del Trabajo, que se encuentran entre los documentos considerados en el documento 2030 en el campo del empoderamiento de las mujeres, se han incluido para ellos concesiones en el campo de los derechos laborales de las mujeres. La prohibición del trabajo peligroso, las horas de lactancia materna y la licencia por maternidad se encuentran entre estos derechos. En la legislación laboral iraní, estas ventajas también se consideran para las mujeres y, por lo tanto, parece que la legislación laboral iraní está de acuerdo con los instrumentos internacionales. El tema de la igualdad se puede analizar de tal manera que, si bien existen diferencias biológicas y naturales entre hombres y mujeres, esta situación no debe dar lugar a diferencias legales. Básicamente, las diferencias biológicas se refieren a las realidades de la existencia humana, y el debate legal se refiere a las necesidades humanas y, aunque los 
individuos son diferentes en las realidades existenciales, también pueden ser similares en los requisitos legales.

Palabras clave: Derecho a la educación, derecho laboral de la mujer, jurisprudencia y derecho iraníes, documento de la UNESCO 2030

\section{Introduction}

Empowerment of all women and girls is an important pillar of the fifth goal of the 2030 document. The right to education and labor rights and the guarantee of full and effective participation and equal opportunities are among the most important partial goals of empowering all women and girls in the second pillar of the 2030 document that in this article, it is examined from the perspective of jurisprudence and law. Some of the goals of the 2030 document include "primary education", "secondary", "quality assessment and evaluation, etc. from elementary school to university; The goal is gender equality and the removal of gender barriers. Governments also need to develop policies that properly respect the rights of women and men, as well as training and planning spaces related to these policies. Elimination of discrimination and gender stereotypes from important goals The fifth goal of the 2030 document should be to address gender-based issues in the field of education ... discrimination based on gender and violence in educational institutions to guarantee the equal effect of education and learning on girls, boys, women and men, and to eliminate gender-based stereotypes and to help promote and promote equality between women and men. In addition to policy-making and planning ... through early use of education ${ }_{s}$ Especially by women and girls and adult learning, as well as promoting opportunities for education and training of young people and adults in all age groups and from any group, with the aim of empowering them, he paid special attention to the issue of gender equality and the removal of gender barriers, as well as to the vulnerable groups. According to the fifth goal of the 2030 document, the goal of education is to eradicate gender inequalities and ensure equal access to all educational levels for vulnerable groups by 2030. Also, while paying special attention to gender norms, as a tool for measuring progress, it is necessary to make more efforts to achieve it. Based on what has been said, the main question is how the right to education and women's labor rights in Iranian jurisprudence and law and the 2030 UNESCO document can be assessed? In order to study and answer the mentioned question, first, the right to education and then women's labor rights in Iranian jurisprudence and law are explained and analyzed.

\section{The right to education of women from the perspective of the 2030 document and jurisprudence and law}

The 2030 document emphasizes women's empowerment. In this article, the right to education of women as one of the most important mechanisms for women's empowerment from the perspective of the 2030 document and jurisprudence and law is examined.

\section{The right to education of women from the perspective of the 2030 document}

The right to education is one of the most fundamental human rights in the world today, and in many documents governments are committed to enforcing this right for the general public. Former UN Special Rapporteur on the Right to Education Katrina Tomasowski points out that there are many human rights problems that cannot be resolved Unless the right to education is addressed as the key that unlocks all other locks on human rights" (Stamatolo, 2013: 67). The right to education is not limited to the elementary school or a certain age. This right is an important tool for improving the quality of life of humanity. It is a tool through which everyone is able to be 
aware of their other rights and responsibilities, as well as a necessary means to achieve the goals of equality between men and women and peace and prosperity. The right to education or the right to study includes the acquisition of information through primary and general education and the practical specialization through applied education, such as technical and vocational education. Because unlike the old world today, the family alone is not able to pass on all the necessary education to their children. Because living a normal life in today's world requires skills that are beyond the family's ability to pass on to children. This is why the need to emphasize this right is so important. Of course, some have taken the interpretation of the freedom of education in a different sense. In this definition, individuals should be able to transfer their education and training methods to their own children and even others by establishing special schools, and consequently the government should consider the minimum restrictions in this way.

Intrinsic Dignity and Human Dignity If some believe that "it is still an ambiguous concept" (Marshall, 2009; 24). But the preamble to the Covenant on Economic, Social and Cultural Rights recognizes it as the basis of the protection of human rights (Ibid, p; 24). Accordingly, the right to education as an economic, social and cultural right is one of the basic human needs. Thus, "the most important philosophical basis of truth is the teaching of the inherent dignity of human beings"; (Beiter. 2006; 489-490). This right, as an "empowering" right, will provide the individual with the ability and talent to enjoy his or her other rights and duties. (Glendyne R, 2011; 8).

This shows the direct connection of education with the dignity and human dignity of individuals (IbidI, p; 8). The right to education is a multifaceted right. This right is "classified as an economic, social and cultural right... Also, the right to education for various reasons is both a civil right and a political right, because this right is the center of gravity of the full and effective realization of those rights. The right to education therefore focuses on the indivisibility and interdependence of all human rights".

Pursuant to article 1 of the UNESCO recommendation on education for understanding, cooperation and international peace, and education in the field of human rights and fundamental freedoms, education "It is all the processes of social life that individuals and social groups learn to consciously" cultivate "to the full benefit of all abilities, talents, inclinations and personal knowledge" (Dieter Beiter, 2006; 18). According to this definition, the right to education as an empowering right will flourish the individual's ability to take full advantage of his or her talents. (Coomans, 1995; 1-2).

Article 1 paragraph 2 of the UNESCO Convention against Discrimination in Education (1960) "All forms and levels of education, including access to education, the standard and quality of education and the conditions under which education is provided" are part of the right to education.

The concept of the right to minimum education also means that all persons, including children, adolescents and adults, have the right to equal access to educational opportunities which can meet their minimum needs. In this sense, the right to education includes "the enjoyment of education in the system of national, provincial and local education, both public and private, in which international instruments generally use education in this sense" (Dieter Beiter, 2006; 17: Verheyde, 2005; 25-26).

The Charter of the United Nations does not explicitly define the right to education, but implicitly refers to it as a reference to international economic, social and cultural problems. Furthermore, the improvement of human rights for all without discrimination, as emphasized in the Charter, paves the way for the future development of the non-discriminatory nature of the right to 
education (IbidI, p; 37). Introduction The UNESCO Charter recognizes education as the cornerstone and necessity of the programs of this organization to promote justice, freedom and peace for human dignity. The Universal Declaration of Human Rights is the first international document to recognize the right to education as a human right. Article 26 of the Declaration, without providing a definition of the right to education, describes the content and elements of this right, including free and compulsory.

The right to education is mentioned in various international and regional documents, and almost all of them have provided specific criteria and guidelines for this right; Among these, the International Covenant on Economic, Social and Cultural Rights has a special place. Article 31 of the Covenant recognizes the right of everyone to free education and declares that the purpose of education shall be to promote human dignity and, ultimately, to international peace. In the second paragraph, this article describes the different courses and requirements related to each level and the third paragraph talks about educational freedom, which is a part of parents' freedom in choosing a school for their children and the other part discusses the freedom of individuals to establish and run educational institutions. Paragraph 2 of Part A of Article 31 emphasizes that compulsory and free primary education shall be made available to the public Article 31 also deals specifically with primary education and calls on the governments to consider the necessary measures for the full implementation of compulsory and free primary education in their country if they have not been able to do so within two years; And interpretative theory No. 33 in this regard has been presented by the Committee on Economic, Social and Cultural Rights.

\section{The right of women to be educated in jurisprudence and law}

A review of religious teachings shows that the right to education is not gendered, but that there are many recommendations for women and men to acquire knowledge. Learning some sciences in Islam is an objective obligation. Some other sciences, although not obligatory for women to acquire, have been taught to women. The view of the laws is the same as the view of the religious teachings of Islam, but little emphasis has been placed on sciences that are objectively obligatory or sciences that are recommended for women.

The Messenger of God (PBUH):

"It is obligatory on every Muslim to seek and acquire knowledge". This hadith is one of the Muslim hadiths that Shiites and Sunnis have quoted from the Holy Prophet (PBUH). (Klini, 1987:

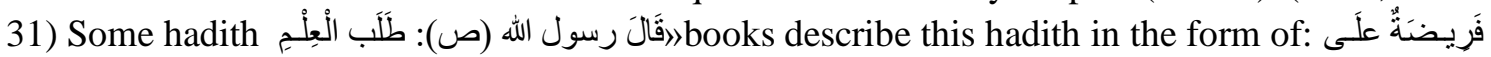

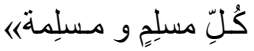

The Messenger of God (PBUH) said: Seeking knowledge is an obligation on every Muslim man and woman. They also narrated (Majlisi II, 1984 AH, J1: 177; Nouri, 1988 AH, J17: 249) that can be a proof of the right of women to education.

$$
\text { عَلَيكُم مِنْ طَلَب الْمالِ: :Imam Ali (AS) }
$$

O people, know that the perfection of religion requires knowledge and working with it Ala, and if the demand for knowledge necessitates you from seeking money:O people, know that the perfection of religion requires knowledge and practice of it; Be aware that seeking knowledge is more obligatory on you than seeking wealth. "(Klini, Previous, vol. 1, p. 31)

تفقهوا في الدين فإنه من لميتفقه منكم فيالدين فهو أعرابي Aba Abdullah (AS): 
Find out about religion. Those who do not divide in religion are Arabs." This hadith in confirmation of verse 122 is Surah Tawbah:

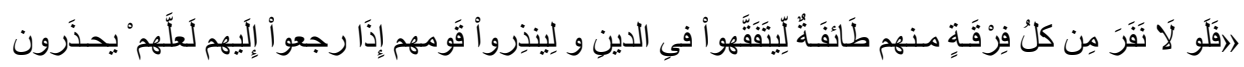

So why do not any of them (believers) move their hands to gain knowledge in the religion and warn their people when they return to them? "Should they fear [God's punishment]?" The purpose of jurisprudence in religion is to understand all religious teachings from its principles and subprinciples, especially practical rules, which are now termed in the language of religious sciences, the word of jurisprudence about practical rules, because it says:

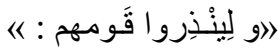

and it is clear that warning is not done by expressing idiomatic jurisprudence, that is, by saying practical issues, but it needs to express the principles of beliefs. (Tabatabai, 1998, J 9: 404) A Bedouin is an ignorant commoner of the religion. These people live in the deserts and do not come to the city except for worldly needs. These people are the same ones that God has said in the Qur'an:

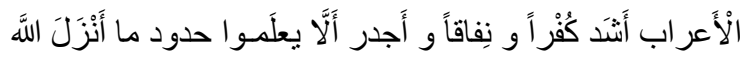

The Arab Bedouins are harder in disbelief and hypocrisy (than others), and more deserving of not knowing the limits of what God has revealed to His Messenger (Tawbah/97). On the other hand, he is an immigrant Bedouin who leaves his homeland to acquire insight into religion and to study jurisprudence and certainty. (Feyz Kashani, 1986 AH, vol. 1: 127-128)

The Constitution of the Islamic Republic of Iran (The Constitution of the Islamic Republic of Iran together with the amendments, changes and completion approved by the Constitutional Review Council in 1989) in various principles has emphasized the right of all individuals to education in all sciences.

According to Article 3, Principle 3 of the Constitution of the Islamic Republic of Iran: "Free education and physical training for all at all levels, and the facilitation and generalization of higher education".

According to Article 20: "All members of the nation, men and women alike, shall be protected by law and shall enjoy all human, political, economic, social and cultural rights in accordance with the principles of Islam".

According to Article 21: "The government is obliged to guarantee women's rights in all respects in accordance with Islamic norms and to create favorable conditions for the development of women's personality and the restoration of their material and spiritual rights." According to Article 30: "The government is obliged to provide free educational facilities for the whole nation until the end of high school and to expand higher education facilities free of charge up to the level of self-sufficiency of the country."

\section{Women's labor rights from the perspective of the 2030 document}

The UNESCO 2030 document does not detail women's labor rights. This document emphasizes the empowerment of women to enjoy equal opportunities, including equal labor rights. Accordingly, in order to explain the right to equal work, the 2030 document as one of the mechanisms for women's empowerment, 
international documents in this regard must be explained and analyzed. The International Labor Organization has sought to protect the rights of working women by ratifying various conventions. Support for pregnant women is one of the issues supported by the International Labor Organization. This organization has dealt with this issue in two conventions No. 3, approved in 1919 and Convention No. 301 (revision), approved in 1951. Other rights for pregnant working women include care and cash benefits. According to Convention No. 3, in the days when a woman is absent from work as maternity leave, sufficient cash benefits must be paid to her and her child for full and hygienic maintenance, either from the general budget or through the insurance system. In addition, she will be entitled to free care by a doctor or midwife.

Also in accordance with Convention No. 301, during the absence from work as maternity leave, a woman should be entitled to sufficient cash benefits to support herself and her child in accordance with an adequate standard of living and enjoy medical benefits, including antenatal, postnatal and postnatal care, and, if necessary, hospital care. The freedom to choose a doctor and the freedom to choose between a public and a private hospital must be respected.

The agreement also states that these benefits must be provided either through compulsory social insurance or from the public budget. In the first case, cash benefits should be calculated on the basis of previous receipts and to the extent that it is not less than two thirds of the total receipts of the woman. In no case should the employer be solely responsible for paying the benefits.

Twelve weeks' maternity leave with entitlement to cash benefits and medical care is one of the rights and benefits approved by the International Labor Organization for pregnant working women. Convention No. 3 provides for a period of six weeks before the probable date of delivery and six weeks after delivery. Convention No. 103 also provides for at least 21 weeks of maternity leave, six weeks of which must be used after delivery. This period of leave must be extended for any period from the probable date of delivery to the actual date of delivery, as well as in the case of illness due to pregnancy or childbirth.

Conventions No. 3 and 103 of the prior notice prohibiting the dismissal of a woman who is absent from work as maternity leave or the issuance of a prior notice of dismissal so that its date expires during the absence.

The ban on night work for women in industry is one of the benefits provided by the International Labor Organization for women.

According to Convention No. 89 of 1948, women, regardless of age, should not be employed in any private or public industrial workshop overnight.

Exceptions, suspensions and reductions are permitted in respect of this Standard in cases expressly defined in the Convention. This Convention shall not apply to women holding managerial or technical positions or to women working in welfare health services who do not normally engage in manual labor.

\section{Women's labor rights from the perspective of jurisprudence and rights}

This section examines women's labor rights from the perspective of jurisprudence and law.

\section{Lack of equal pay}


The Iranian constitution does not have an explicit principle of protection of wages, but from the spirit of some principles, this is well understood. In paragraphs 9 and 12 of the third principle, the elimination of undue discrimination and the creation of fair opportunities for all in all material and spiritual fields and the establishment of a correct and just economy in accordance with Islamic criteria to create prosperity and poverty and removes any restrictions in the areas of nutrition, housing, work, health and insurance generalization. Paragraph 1 of Article 43 also provides for the provision of basic necessities for all and in paragraph 4 of the said principle, to prevent the exploitation of another work.

According to Article 23 of the Labor Law adopted in 1337: "The wages of female workers and male workers are equal for equal work." The above article was amended with the approval of the Labor Law approved on 20/11/1990. Article 38 of the recent law stipulates the principle of equal pay: "For equal work to be done under equal conditions in a workshop, men and women must be paid equal wages. Discrimination in determining the amount of wages on the basis of age, sex, race, ethnicity and political and religious beliefs is prohibited".

In 2006, in the report of the Committee of Experts on the implementation of the conventions and recommendations of the International Labor Organization on the implementation of Convention No. 111 in Iran, article 12 deals with the implementation of the principle of non-discrimination in Iran, especially discrimination on the basis of sex, belief and ethnicity and while pointing to the achievements of the Iranian government in eliminating discrimination, some criticisms have been raised.

Although the International Labor Organization Convention No. 100 and 101 and all human rights instruments emphasize the full equality of men and women, and in Article 20 of the Constitution and Article 6 of the Labor Law, equal legal protection of all citizens, male and female specified, but in practice, sex discrimination in the workplace has not disappeared. Of course, there have been achievements in the field of gender inequality during these years. For example, in Article 101 of the Fourth Economic, Social and Cultural Development Plan Law, the government is obliged to "Ensuring equality between men and women for equal work, prohibition of discrimination in employment and occupation, equal opportunities for men and women, and empowerment of women through access to appropriate job opportunities" (Mazrouei, 2006). In addition, some facts have occurred in connection with the elimination of sex discrimination in Iran and, for example, the number of female students has increased significantly. Nevertheless, Iran continues to be criticized for perpetuating some gender inequalities, and in the 2006 report of the Committee of Experts, in addition to some achievements, shortcomings in the prohibition of sex discrimination are listed in six paragraphs.

The Charter of Women's Rights and Responsibilities in the Islamic Republic of Iran has been compiled with the inspiration of the comprehensive Islamic law and its legal system and with the aim of systematically explaining women's rights and responsibilities in the fields of individual, social and family rights. This charter is based on the constitution in order to explain the rights and duties of women in Islam. The Charter of Rights and Responsibilities of Women in the Islamic Republic of Iran, based on the duties of the Supreme Council of the Cultural Revolution, is a reference authority for policy-making in cultural and social affairs and in 3 parts, 5 chapters and 148 clauses were approved on 21/9/2004 in the meeting No. 546 of the Supreme Council of the Cultural Revolution and all relevant agencies are obliged to comply with the rules and principles set forth in this charter in accordance with their institutional and organizational duties for policymaking, legal measures, decisions and planning regarding women. This charter is also the basis 
for introducing and explaining the position of women in the system of the Islamic Republic of Iran in international forums.

The Women's Socio-Cultural Council is obliged to evaluate the situation of Iranian women every two years after the approval of this Charter and submit an evaluation report to the Supreme Council of the Cultural Revolution on the progress made towards its realization and the cases of violations of women's rights. Attempts have been made to mention all the rights and responsibilities of women, whether common between women and men or specifically for women, and the reasons for this are as follows: (Jalali and Mousavi, 2012).

A) Because there is a lot of debate in the international arena about the human rights of women and they are trying to prove human rights in accordance with the Western view of women and on the other hand, different countries have different views and practices in the field of women's human rights based on their cultures, it was necessary to include in the Charter, which reflects the views of the Islamic Republic of Iran she human rights of women, the common rights between men and women and the special rights of women should be expressed in various issues to determine what rights and responsibilities the regime of the Islamic Republic of Iran gives to women.

B) - In Islamic thought, men and women are generally common in their human rights however, since discrimination may occur in the stages of action and implementation, to emphasize, this category of rights is also mentioned as women's rights. (Musafa, 2016: 23).

C) Since this charter only seeks to express the rights of women, it does not mention the rights of other social groups; However, in the implementation phase, according to other laws and policies, the rights of other social groups will also be considered. This charter does not seek to state how rights and duties are enforced, although it is necessary to provide an enforcement guarantee instead of the structure of the law. Because the charter not only seeks to state the rules, but also to pay attention to culture. Therefore, some applicable moral issues are also mentioned in the category of women's rights and responsibilities. The charter tries to mention the general and basic rights and responsibilities as much as possible and to omit the examples. But because the design of some legal cases or responsibilities in international conflicts or domestic culture needs to be emphasized and clarified, it is clearly stated.

\section{Prohibition of dismissal}

Ensuring the job security of working women during pregnancy and childbirth is one of the issues raised in the Convention on the Elimination of All Forms of Discrimination against Women. If the second part of Article 11 of the Convention provides in paragraph (a): "In order to prevent discrimination against women on the basis of marriage or motherhood (pregnancy) and to guarantee their effective right to work, States Parties shall take the following measures:

Prohibition of expulsion due to pregnancy or maternity leave and discrimination in expulsion based on marital ${ }^{1}$ status by establishing an enforcement guarantee for violation of this matter Article 8 of Convention No. 183 the International Labor Organization has also called for a ban on dismissal of working women during pregnancy and childbirth, according to the mentioned article, firstly, the dismissal of a female worker during pregnancy and maternity leave and in the period after returning to the worker after the end of maternity leave, the duration of this period will be determined in the regulations and domestic laws of the countries, except for reasons unrelated to 
pregnancy or childbirth and its complications. Second, the return of the employed woman to a previous or similar job and with a previous receipt after the end of maternity leave is guaranteed.

\footnotetext{
1 - Article 11-2 In order to prevent discrimination against women on the ground of marriage or maternity and to ensure their efective right to work, states parties shall take appropriate measures;

(a) To prohibit, subject to the imposition of sanctions, dismissal on the grounds of pregnancy or of maternity leave and discrimination in dismissals on the basis of marital status;
}

A vital element in maternal support is to support pregnant women and young mothers so that they do not lose their jobs due to pregnancy, childbirth or maternity leave. In other words, pregnancy and childbirth should not be a cause of occupational discrimination against women.

\begin{abstract}
Significant progress has been made today in the need to maintain women's employment while they are on maternity leave. The usual custom in maternity leave is to comply with the "no dismissal of working women" rule. These measures are primarily designed to protect the health of the mother and her unborn child and to ensure a permanent source of income and job security for the mother. In many countries, under the influence of new views of women on employment and as a result of changes in the intellectual responsibilities of women and men over the past decade, workers' maternity protection programs have expanded considerably. Although the ultimate goal is still to protect the health of the mother and her child, it seems that the measures taken in recent years are broader than the employment policies of women. In fact, today these measures are pursued with a just goal, and that goal is to ensure that pregnancy and breastfeeding should not hinder the right of working women to work (Alawi, 2014: 265-258).

The Iranian Labor Law does not explicitly mention the prohibition of dismissal of working women during pregnancy and childbirth, and only in a note to Article 76 of the said law: "After maternity leave, the female worker returns to her former job".This sentence can be considered as an implicit prohibition of dismissal of a female worker and the need to return her to her previous job. In addition to the mentioned law, in the Law on Promoting Breastfeeding and Supporting Mothers during Breastfeeding approved in 1995, job security after maternity leave and during breastfeeding is emphasized in a very general and vague way in Note 2 of Article 3 . It should be noted that the Labor and Social Security Law, as well as the employment laws of the country, do not prescribe dismissal due to pregnancy or maternity leave and if an employed woman is fired only because of pregnancy, in violation of the Labor and Social Security Law or the employment laws of the country, she can refer to the "Discernment Boards of the Ministry of Labor" or the "Court of Administrative Justice" and complain to her respective organization. If these judicial authorities confirm the veracity of the woman's claim, the relevant organization, while returning the woman to work, will be required to pay her salary and receipt during the days of the woman's illegal dismissal. Therefore, the domestic laws of Iran are in accordance with paragraph "a" of Part 2 of Article 11 of the Convention.
\end{abstract}

\title{
Conclusion
}

In the Convention, equality means abrogation and disregard for the gender characteristics of men and women, that is, the abrogation of both men and women in order to achieve full similarity between men and women in rights and duties, is used, whereas in the Constitution of the Islamic Republic of Iran, which is regulated according to Islamic criteria, equality has the second meaning of will; That is, every human being, both men and women, must have appropriate and sufficient opportunities and backgrounds for growth and development and reaching existential perfection and the gender of neither man nor woman should be an obstacle to achieve this sublime desire and whoever makes better use of his opportunities will achieve greater growth and perfection and will be superior to the other. In Islam, the criterion of virtue and superiority is piety and adornment with human and moral virtues, not being a woman or a man. Being a woman is not a defect in itself, nor is being a man a perfection. On the other hand, equality between men and women in the Constitution of the Islamic Republic of Iran is subject to the observance of Islamic norms and this view differs from the conception of the Convention and other international instruments of equal rights for men and women.

Regarding the right of women to education, it should be said that according to paragraph 1 of Article 13 of the International Covenant on Economic, Social and Cultural Rights, the Covenant member states recognize the right of everyone to education and agree that the goal of education should be the full development of the human personality and its sense of dignity and the strengthening of respect for human rights and fundamental freedoms. As a result, international 
instruments have a special view on the right to education and have warned countries against banning the education of individuals in society. Paragraph 3 of Article 3 of the Constitution of the Islamic Republic of Iran recognizes the right to education at all levels for individuals in society. This principle states that the government is obliged to provide all the necessary facilities for free education and physical training for all at all levels, and to facilitate and generalize higher education.

Regarding women's labor rights, it should be said that women's employment is associated with the violation of their labor rights in many. In this regard, at the international level, the International Labor Organization has tried to protect the rights of working women by ratifying various conventions. Support for pregnant women is one of the issues supported by the International Labor Organization. This organization has dealt with this issue in two conventions No. 3, approved in 1919 and Convention No. 301 (revision), approved in 1951. In addition, the 12-week maternity leave entitled to cash benefits and medical care is one of the rights and benefits approved by the International Labor Organization for pregnant working women. Iran, as one of the first countries to become a member of the International Labor Organization and has accepted its conventions, has practically accepted the rights emphasized in the International Labor Organization. International Labor Organization Conventions have been influential in several cases in Iranian labor law, including equal pay. There is no explicit principle in the Iranian constitution that protects wages, but from the spirit of some principles, this is well understood. In paragraphs 9 and 12 of the third principle, the elimination of undue discrimination and the creation of fair facilities for all in all material and spiritual fields and establishment of a correct and just economy in accordance with Islamic norms speaks for the creation of welfare and the elimination of poverty and the removal of any restrictions in the fields of nutrition, housing, work, health, and the generalization of insurance. Paragraph 1 of Article 43 also provides for the provision of basic necessities for all and in paragraph 4 of the said principle, to prevent the exploitation of another work. According to Article 23 of the Labor Law approved in 1959, the wages of female and male workers are equal for equal work. The above article was amended with the approval of the Labor Law approved on 12/20/1990. Article 38 of the recent law on the principle of equal pay stipulates that equal work must be paid to men and women equally in order to perform equal work performed in equal conditions in a workshop. Discrimination in determining wages based on age, sex, race, ethnicity, and political and religious beliefs is prohibited.

\section{References}

Alaviun, Seyed Mohammad Reza. (2014). Women's Labor in Iranian Law and International Labor Law, Tehran: Roshangaran Publications and Women's Studies.

Beiter. K.D. (2006). The Protection of the Right to Education by International Law, Boston: Martinus Nighoff,pp;489-490

Coomans, Fons and Van Hoop (eds). (1995). The Right to Complain aboat Economic Social and Cultural Rights, Utrecht: Stichting Studie En Infermatie Centurm Mensenrechten,p;1-2.

Dieter Beiter, Klaus. (2006). The Protection by International Law; Incuding a Systematic Analysis of Article 13 of the International Covenant on Economic Social and Cultural Rights, Martinus Nijhoff Publishers,p;18. 
Dieter Beiter, Klaus. (2006). The Protection by International Law; Incuding a Systematic Analysis of Article 13 of the International Covenant on Economic Social and Cultural Rights, Martinus Nijhoff Publishers,p;17

Faiz Kashani, Mohammad Ibn Shah Morteza. (1986). Al-Rasa'il al-Fiqhiyyah, edited and researched by Seyyed Abolghasem Naqibi, vol. 1, Tehran, Shahid Motahari High School.

Glendyne R. Wergland. (2011). Sisters in the Faith: Shaker Women and Equality of the Sexes (Amherst: University of Massachusetts Press, 2011Verheyde, Mieke; (2005),Article 28: The Right to Education; in: A. Alen, J. Vande Lanotte, E.Verhellen, F. Ang, E. Berghmans and M. Verheyde (Eds.) A Commentary on the United Nations Convention on the Rights of the Child,Martinus Nijhoff Publishers, Leiden,p;25-26.

Jalali, Mohammad and Mousavi, Seyedeh Fatemeh. (2012). Women's Rights from the Perspective of Islam and International Human Rights Documents, Journal of Women and Culture, Fourth Year, No. 15.

Klini, Abu Ja'far, Muhammad ibn Ya'qub. (1987). Al-Kafi, vol. 11, Tehran: Islamic Library.

Majlisi, Mohammad Baqir. (1984). Bihar Al-Anwar, vol. 1, Beirut: Al-Wafa Institute, second edition.

Marshall, T. M. (2009). Citizenship andSocial Class. In B. S. Turner \& P. Hamilton, Citizenship: Critical Concepts. London: Routledge.,p;24.

Mazrouei, M. (2006). Labor Law Amendment and Tripartism, Phoenix Publications, Tehran.

Musafa, Nasrin. (2016). the role of UNESCO in the promotion of science, Science Promotion Quarterly, first year, first issue.

Nouri Tabarsi, Hussein. (1988). Mustadrak al-Wasa'il, vol. 17, second edition, Beirut: Al-Bayt (AS) Foundation for the Revival of Heritage.

Stamatolo, Elsa. (2013). Cultural Law in International Law, translated by Qasem Zamani and Mena Sadat Mirzaei, Tehran, Khorsandi, first edition.

Tabatabai, Seyyed Mohammad Hussein. (1992). Al-Mizan, (Translation: Seyyed Mohammad Baqir Hamedani), vol. 9, Qom, Qom Islamic Propaganda Office. 